\title{
ARGUMEN A FORTIORI DAN ARGUMEN A CONTRARIO DALAM HUKUM ISLAM DAN HUKUM POSITIF
}

\author{
Marwadi
}

\begin{abstract}
Understanding law is not only to know explicitly but also to know implicitly. It can be used for finding out the 'law cause' or illat as the cause for analogizing the situation. In Islamic law the study of enlarging understanding is wider than positive law since there is a difference between analogical interpretation and a fortiori argument.
\end{abstract}

Kata kunci: argumen a fortiori, argumen a contrario, bukum Islam, bukum positif

\section{A. Pendahuluan}

Suatu teks sumber hukum atau undang-undang, kadang-kadang dapat memberikan pengertian yang bermacam-macam karena dilihat dari cara-cara yang digunakan oleh para ahli hukum untuk memahami petunjuknya. Mengambil petunjuk suatu teks tidak terbatas hanya dengan memahami apa yang tersurat dalam susunan kalimat suatu teks, akan tetapi dapat juga dengan mencari apa yang tersirat dibalik

- Dosen Jurusan Syari'ah STAIN Purwokerto, alumni Program S2 Hukum Islam LAIN Sunan Kalijaga. 


\section{Marwadi}

susunan kalimat itu, mencari kausa hukum atau 'illah yang menjadi sebab ditetapkannya suatu hukum untuk dijadikan tempat menganalogikan peristiwa yang tidak ada teksnya. Juga dengan jalan mencantumkan kata yang tepat sehingga pengertiannya menjadi rasional. Cara-cara tersebut oleh ahli hukum dinamakan dengan penalaran teks.

Petunjuk teks dalam sumber hukum maupun undang-undang dapat berupa petunjuk dari makna teks yang jelas dan dapat berupa petunjuk dari makna teks yang tidak jelas. Petunjuk dari makna yang tidak jelas terbagi menjadi: ${ }^{1}$

1. Makna yang terdapat di dalam teks itu yang dikehendaki oleh pembuat teks, terbagi lagi menjadi:

a. Kata yang tidak disebutkan dalam teks itu menjadi penentu benar atau sahnya suatu makna teks, artinya pemahaman terhadap makna teks tidak akan lengkap tanpa mendatangkan kata yang tidak terdapat dalam teks itu;

b. Teks yang memberikan petunjuk kapada suatu makna yang diperoleh dari kata yang disebutkan, akan tetapi benar tidaknya pengertian itu tidak semata-mata tergantung kepada kata itu;

c. Teks yang memberikan makna hukum yang diperoleh bukan dari kata yang disebutkan, baik hukum itu sesuai dengan maksud hukum dari kata yang disebutkan maupun berbeda. Penalaran inilah yang disebut dengan pemahaman teks. Jika dalam penalaran itu memunculkan hukum yang sesuai dengan hukum yang diambil dari kata yang disebutkan, maka penalaran tersebut dinamakan argumen a fortiori atau mafbum al-muwäfaqah. Akan tetapi jika hukum yang ditetapkan kepada kasus yang tidak disebutkan oleh teks berbeda dengan hukum yang diterapkan kepada hukum yang disebutkan dalam teks, maka penalaran tersebut dinamakan argumen a contrario atau mafbüm al-mukhālafah.

'Muhtar Yahya dan Fatchurahman, Dasar-Dasar Pembinaan Hukum Figh Islam, (Bandung: Alma'arif, 1993), hal. 306-310. 
2. Makna yang terdapat dalam teks itu tidak dikehendai oleh pembuat teks akan tetapi makna itu tidak dapat dipisahkan dengan makna yang terdapat dalam teks.

Tulisan ini berupaya menjelaskan bagaimana penggunaaan dua tipe pemahaman (argumen) di atas, yaitu argumen a fortiori dan argumen a contrario dalam hukum Islam dan hukum positif.

\section{B. Argumen a Fortiori dalam Hukum Islam}

Barangkali argumen yang paling jelas dikenal oleh kaum usüliyyun adalah argumen a fortiori (mafbüm al-muwäaqaah) dalam kedua bentuknya yaitu a minori ad maius (fahwā al-kbitäb) dan a maiori ad minus (laḥn al-khițāb). Argumen a fortiori (mafhüm al-muwäaqaah) menurut Wahbah al-Zuhayli adalah: ${ }^{2}$

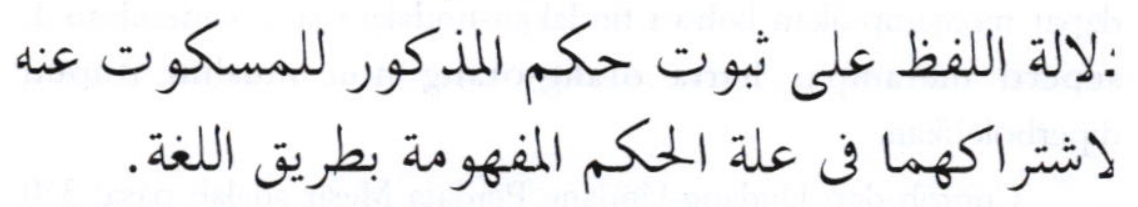

Sedangkan Badrān mengartikan argumen a fortiori (mafbüm almuwäfaqab) sebagai pernyataan yang menunjukkan berlakunya hukum kasus yang disebutkan karena adanya causa legis yang sama antara keduanya yang dapat dipahami dari pernyataan itu sendiri. ${ }^{3}$ Dengan kata lain argumen a fortiori adalah suatu argumen berdasarkan substansi makna yang terkandung dalam ungkapan yang mencakup kasus yang disebutkan untuk memberlakukan hukum kasus itu pada kasus lain serupa yang memiliki substansi yang sama. ${ }^{4}$

Dalam menguraikan model-model penalaran yang tercakup dalam konsep qiyas, al-Syafi'i mengatakan bahwa bentuk qiyas yang paling kuat dapat diilustrasikan melalui contoh tatkala Allah atau Rasul-Nya melarang sejumlah zat tertentu, kitapun menyimpulkan

${ }^{2}$ Wahbah al-Zuhayli, Ușül al-Figh al-Islämi (Beirut: Där al-Fikr, 1986), I: 362.

${ }^{3}$ Badrān Abu al-'Aynayn Badrān, Ușül al-Figh al-Islämī (Iskandariyah: Mu'asssasah Syabāb al-Jāmi'ah, t.t.), hal. 421.

"Syamsul Anwar, "Argumentum A Fortiori dalam Metode Penemuan Hukum Islam" dalam Sosio-Religia, 1, 3 (2002), hal. 7. 


\section{Marwadi}

bahwa sejumlah besar zat itu juga dilarang. Begitu pula jika mengkonsumsi bahan makan tertentu dalam jumlah besar dibolehkan maka bahan makanan itu dalam jumlah kecil juga dibolehkan. Sebagai contoh inferensi pertama yang dalam istilah yurisprudensi Barat disebut dengan a minori ad maius, al-Syafi'i mengutarakan ayat alQur'an yang artinya: “maka barang siapa yang mengerjakan kebaikan seberat biji zarrah pun ia pasti akan melihatnya dan barang siapa mengerjakan kejahatan seberat zarrah pun iapun pasti akan melihatnya." Dari sini bisa dipahami bahwa ganjaran bagi mengerjakan kebaikan lebih dari berat zarrah dan hukuman bagi mengerjakan kejahatan lebih dari berat zarrah adalah bersifat substansial ketimbang yang dijanjikan bagi seberat zarrah. Contoh argumen kedua, a maiori ad minus, adalah wahyu Allah yang membolehkan membunuh orangorang non muslim yang memerangi kaum muslim. Dari teks ini orang dapat menyimpulkan bahwa tindakan-tindakan selain membunuh seperti merampas harta orang-orang non muslim itupun diperbolehkan. ${ }^{5}$

Contoh dari Undang-Undang Perdata Mesir adalah pasal 370 menyebutkan bahwa orang yang menyewakan tidak boleh dibebani untuk mengerjakan perbaikan apapun kecuali apabila hal tersebut diisyaratkan penetapannya dengan hal itu pada waktu akad. Dari mafhüm-nya dapat dipahami bahwa orang yang menyewakan tidak boleh dibebani untuk membuat kamar karena hal ini lebih berat daripada mengerjakan perbaikan dengan adanya 'illab larangan pembebanan yaitu adanya saling merelakan terhadap sesuatu yang diperjanjikan.

Pada pasal 274 disebutkan bahwa wanita yang bersuami yang terbukti berzina dihukum kurungan selama waktu yang tidak lebih dari dua tahun. Akan tetapi suaminya berhak untuk menghentikan eksekusi hukum tersebut dengan kerelaannya untuk menggaulinya sebagaimana semula. Dari dalälah nash ini dipahami bahwa si suami berhak pula menuntut penghentian tuduhan zina sebelum putusan.

\footnotetext{
${ }^{5}$ As-Syafi'i, Ar-Risalah, teri. Ahmadi Thoha (Jakarta: Pustaka Firdaus, 1983), hal. 245.
} 
Karena seseorang yang memiliki hak menghentikan eksekusi hukum sesudah dikeluarkan maka lebih lagi ia memiliki hak untuk mengehentikan proses pendakwaan mengenai zina itu.

Dalam pasal lain yaitu pasal 237 disebutkan bahwa orang yang sedang memergoki istrinya berbuat zina dan membunuhnya maka ia dikenakan kurungan sebagai ganti hukuman yang ditetapkan pada pasal 234 dan 236. Dari dalälab nas ini dapat dipahami bahwa sekiranya kalau ia memukul istrinya dengan suatu pukulan yang menyebabkan sakit yang lama maka hal itu hanya dianggap sebagai kesalahan bukan tindak pidana karena hal itu jauh lebih ringan daripada pembunuhan. ${ }^{6}$

Para ahli usul fikih memperdebatkan apakah argumen a fortiori termasuk ke dalam qiyas atau pemahaman langsung dari teks. Para Mutakallimin, kecuali al-Ghazali, penganut mazhab Z̄ahiri dan beberapa ulama Hanafiah berpendapat bahwa argumen a fortiori tidak merupakan penalaran inferensial melalui qiyas, melainkan penalaran linguistik ketika hukum dipahami sebagai implikasi bahasa teks itu sendiri. Tokoh-tokoh usul fikih Hanafiah seperti al-Bazdawi, asSarakhshi, an-Nasafi, al-Bukhāri dan al-Miḥlawi menegaskan bahwa hukum yang ditetapkan berdasarkan argumen a fortiori disimpulkan dari bahasa teks tanpa melalui ijtihad dan penyimpulan rasional serta dapat diketahui oleh setiap orang yang memahami dan menguasai bahasa teks bersangkutan. Argumen a fortiori bukan merupakan qiyas karena qiyas hanya dapat dipahami oleh ahli hukum, sedangkan argumen a fortiori dapat dipahami orang yang memahami bahasa. ${ }^{7}$

Sejalan dengan pandangan di atas adalah pendapat Abū Ya'lā al-Farrā' dari mazhab Hanbali dan al-Āmidi dari mazhab Syafi'i. Sebaliknya beberapa ahli hukum mazhab Syafi'i seperti al-Shirāzi dan al-Māwardi termasuk al-Syafi'i sendiri menganggap argumen a fortiori termasuk ke dalam qiyas. Al-Shīrāzi mengatakan bahwa argumen a fortiori melibatkan suatu penalaran inferensial karena di

"Abd al-Wahhāb Khallāf, 'Ilm Ușül al-Fiqh (Ttp.: Dār al-'Ilm, 1978), hal. 147.

${ }^{7}$ Syamsul Anwar, "Argumentum," hal. 10. 


\section{Marwadi}

dalam argumen ini bahasa teks tidak secara tersurat menyebutkan hukum masalahnya. Memukul tidak dipahami dari kata hus. Dengan penalaran mengenai implikasi dapat dipahami bahwa kata hus mengandung arti menyakiti dan karena itu meliputi juga memukul.

Sedangkan al-Ghazali mengambil jalan tengah di antara dua pandangan di atas. Menurutnya argumen a fortiori tidak dianggap sebagai qiyas dan keliru orang yang menganggap larangan memukul orang tua itu didasarkan kepada qiyas terhadap larangan mengucapkan kata hus. Dalam larangan mengucapkan hus yang pokok untuk ditegaskan adalah bukanlah larangan mengucapkan hus itu sendiri tapi penegasan sesuatu yang tidak tersurat yaitu genus larangan menyakiti orang tua dengan menyebutkan contoh spesifiknya saja. Sebaliknya tidak tepat pula untuk mengatakan bahwa argumen a fortiori merupakan kesimpulan yang dipahami dari bahasa itu sendiri. Karena ucapan seseorang "jangan engkau mengatakan hus" tidak dimaksudkan untuk menyatakan larangan memukul. Menurutnya larangan yang lebih kecil tidak serta merta melarang yang lebih besar selama konteks dan qarinab yang menyertai ucapan tidak dipahami. Kontekslah, menurutnya, yang menunjukkan adanya makna a fortiori yang tidak disebutkan itu dan dengan bantuan konteks pemahaman itu dapat ditingkatkan ke level yang lebih pasti. Oleh karena itu tidak tepat pernyataan bahwa argumen a fortiori merupakan pemahaman dari bahasa teks itu sendiri. Dalam mengartikan argumen a fortiori, al-Ghazali mengatakannya sebagai "memahami makna yang tidak tersurat melalui ungkapan tersurat dengan petunjuk konteks dan maksud pernyataan."

\section{Argumen a Contratio dalam Hukum Islam}

Argumen a contrario (majbüm al-mukbälafab) dapat didefinisikan sebagai: ${ }^{9}$

\footnotetext{
${ }^{8}$ Ibid., hal. 13-14.

9 Al-Zuhayfi, Ușül al-Fiqh, hal. 362.
}

Al Manāhij, Vol. 2 No. 1 Januari - Juni 2008 


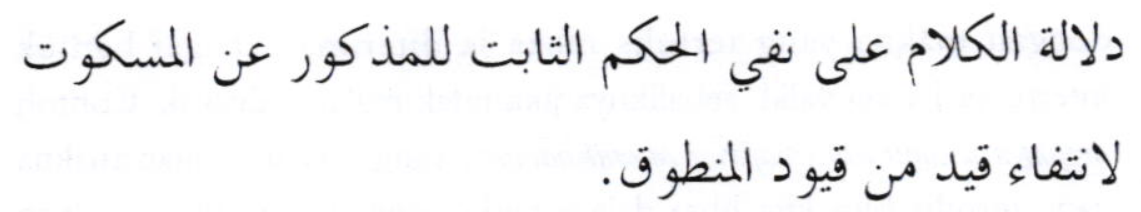

Dapat juga didefinisikan dengan: "makna yang diambil dari kata-kata teks, yang berlawanan dengan makna eksplisit yang terdapat di dalamnya." Dengan ungkapan lain argumen a contrario (mafbum almukhälafab) adalah penetapan lawan hukum yang diambil dari dalil yang disebutkan dalam teks (mantūq bih) kepada sesuatu yang tidak disebutkan dalam teks (maskūt 'anbu) sehingga hukum yang ditetapkan oleh masküt 'anbu adalah berlawanan dengan hukum yang ditetapkan oleh mantūq bih. ${ }^{10}$

Contohnya al-Qur'an menyatakan secara umum tentang kebolehan makanan bagi manusia dengan sedikit pengecualian yang dikemukakan dalam teks selanjutnya "katakan aku tidak menemukan larangan apapun dalam wahyu yang diturunkan kepadaku bagi orang yang ingin makan kecuali bangkai dan darah yang mengalir." Dengan melihat kepada bagian terakhir dari teks ini, apakah sah untuk mengatakan bahwa darah yang tidak mengalir adalah halal untuk dimakan? Jawabannya tidak. Dengan kata lain teks itu diberikan interpretasi yang sebagian besar tampaknya berlawanan dengan maknanya yang tampak, karena kebolehan darah yang tidak mengalir seperti hati dan limpa bukan ditentukan oleh ayat itu tetapi oleh hadis yang tersendiri. Hati dan limpa halal dimakan karena adanya hadis Nabi yang menyatakan bahwa "halal bagi kita dua jenis bangkai dan dua jenis darah, yaitu ikan dan belalang serta hati dan limpa."11

Sebagaimana ditegaskan bahwa argumen a contrario (mafhü almukhälafah) berlawanan dari makna yang tertulis (dalalah mantüq), tetapi kedua makna itu kadang-kadang sejalan dan kadang-kadang tidak. Hanya apabila argumen a contrario (mafhüm al-mukhälafab) sejalan

${ }^{10}$ Ibid., hal. 360. Lihat pula Muhammad Hashim Kamali, Prinsip-prinsip dan Teori Hukum Islam, terj. Nurhaidi (Yogyakarta: Pustaka Pelajar, 1996), hal. 168. Khudari Bik, Ușül al-Fiq, (Ttp. Dar al-Fikr, 1988), hal. 122.

"Khallāf, 'Ilm Ușul al-Fiqh, hal. 154. 


\section{Marwadi}

dengan makna yang tertulis maka ia diterima sebagai bentuk interpretasi yang valid, sebaliknya jika tidak maka ia ditolak. Contoh argumen a contrario (mafhüm al-mukhälafah) yang sesuai dengan makna yang tertulis bisa kita lihat dalam hadis yang mennyatakan bahwa "apabila air mencapai dua kullah maka ia tidak mengandung najis". Atas dasar argumentasi ini, maka apabila suatu kotoran jatuh ke dalam air yang kedalamnya dua kullah maka air itu tetap dianggap suci untuk berwudlu. Inilah makna tertulis atau makna eksplisit teks. Dengan mafhüm al-mukhälafah diperoleh pengertian bahwa air yang tidak mencapai dua kullah dapat menyimpan kotoran. Inilah interpretasi yang dianggap sejalan dengan makna tertulis dari hadis tersebut. $^{12}$

Dalam perundang-undangan disebutkan misalnya pasal 466 Undang-Undang Perdata Mesir yang menyatakan "apabila seseorang menjual sesuatu yang ditentukan substansinya, padahal ia tidak memilikinya, maka pembeli dapat menuntut pembatalan jual beli itu”. Dalam pasal 468 dinyatakan "apabila telah diputuskan bagi pembeli tentang pembatalan jual beli, dan ia tidak mengetahui bahwa barang yang dijual bukanlah milik si penjual, maka ia berhak untuk menuntut penggantian, kendatipun penjual mempunyai niat yang baik". ${ }^{13}$

Ada beberapa macam argumen a contrario (mafbüm al-mukhälafab) yaitu: ${ }^{14}$

1. Mafhum sifah. Seperti dalam firman Allah "dan isteri-isteri anak kandungmu". Mafbüm-nya adalah isteri-isteri anak yang tidak sekandung.

2. Mafbüm ghäyah (batas maksimal). Seperti pada firman Allah "kemudian jika si suami menthalaknya (sesudah thalak yang kedua) maka perempuan itu tidak halal baginya kecuali dia kawin dengan suami lain. Mafbüm mukhalafabnya ialah apabila wanita

${ }^{12} \mathrm{~K}$ amali, Prinsip-Prinsip, hal. 170.

${ }^{13}$ Khalläf, 'Ilm Ușül al-Fiqh, hal. 160.

${ }^{14}$ Ibid., hal. 229-232. 
Argumen A Fortiori Dan Argumen A Contrario...

yang telah diceraikan tiga kali menikah dengan laki-laki selain yang menceraikan.

3. Mafbüm syarat. Seperti dalam firman Allah "dan jika mereka (isteriisteri yang sudah di thalak) itu sedang hamil maka berikan kepadanya nafkahnya sampai mereka bersalin. Mafhüm mukhälafah-nya jika isteri yang dithalak tersebut tidak dalam keadaan hamil.

4. Mafbüm 'adad. Seperti daam firman Allah "maka deralah delapan puluh deraan." Mafbüm mukhälafah-nya yang lebih sedikit dan lebih banyak dari delapan puluh.

5. Mafbüm laqab (nama). Seperti dalam kalimat "Muhammmad Rasulullah”. Mafhüm mukhälafab-nya adalah selain Muhammad.

Para ulama ushul sepakat untuk tidak mempergunakan bujah dengan nash atas dasar mafhüm al-mukhälafah dalam satu bentuk, sepakat untuk menjadikan bujjab dalam satu bentuk dan berselisih dalam bentuk lainnya. Adapun mafbüm al-mukhälafah yang mereka sepakati untuk tidak mempergunakan teks sebagai bujjah berdasarkan mafhüm al-mukhälafah-nya adalah mafbüm laqab. Bentuk mafhüm almukhälafah yang mereka sepakati untuk mereka pergunakan sebagai hujjah maka itu adalah mafhüm sifah, mafbüm syarat, mafbü 'adad, dan mafhüm ghāyah tetapi dalam bidang selain nas syar'i, misalnya dalam berbagai perjanjian antara mereka yang mengadakan perjanjian dan tasharruf, perkataan manusia dan lain-lain. Adapun bentuk mafbüm al-mukhälafah yang masih diperselisihkan mengenai pemakaiannya adalah mafhüm al-mukhälafah pada sifat, syarat, batas maksimal dan perhitungan terhadap nas syari. ${ }^{15}$

Menurut ulama-ulama Syafi'iyah, deduksi dengan menggunakan mafhüm al-mukhālafah hanya bisa diterima jika memenuhi syarat-syarat berikut:

1. Mafbüm al-mukhälafah tidak keluar dari dalälah mantūq. Misalnya ayat al-Qur'an yang melarang mengucapkan uff pada orang tua

${ }^{15}$ Ibid., hal. 232-235. 


\section{Marwadi}

tidak bisa menggunakan mafhüm al-mukhälafah sehingga penghinaan fisik menjadi boleh;

2. Mafbüm al-mukbālafah tidak keluar dari kedudukannya semula karena alasan seperti takut atau tidak tahu. Misalnya bila seseorang menyuruh pembantunya untuk membagikan zakat kepada orang-orang muslim, tetapi dengan mengatakan begitu ia bermaksud agar zakat itu diberikan kepada orang-orang yang benar-benar membutuhkan tidak peduli apakah muslim atau non muslim. Tetapi hal ini tidak disebut karena khawatir dituduh menyulut terjadinya perpecahan oleh sesama umat Islam. Jika ada bukti yang mendukung kekhawatiran itu, maka mafbum almukhālafah harus diterapkan;

3. Mafbüm al-mukhälafah tidak bertentangan dengan sesuatu yang dominan dalam masyarakat dan menjadi adat istiadat. Contohnya ayat yang menjelaskan tentang bentuk perkawinan yang diharamakan "dan haram bagi kamu anak-anak tiri perempuan yang tinggal bersamamu yang lahir dari isterimu yang telah kamu setubuhi". Berdasarkan mafbüm al-mukhälafah maka mengawini anak tiri yang tidak berada di dalam perawatannya adalah halal. Tetapi ini makna yang didasarkan pada sesuatu yang tidak lazim dalam masyarakat karena biasanya anak tiri tinggal bersama ibu dan ayah tirinya. Dengan demikian ayat ini tidak berarti melegalisasi perkawinan seseorang dengan anak tirinya yang tidak tinggal serumah dengnanya;

4. Teks asal tidak diturunkan untuk menjawab persoalan khusus. Misalnya Nabi pernah ditanya apakah ternak yang tidak digembalakan tidak dikenai zakat?, dia menjawab dengan nada afirmatif. Tetapi jawaban ini tidak menyatakan secara tegas bahwa ternak yang digembalakan tidak dikenai zakat. Jawaban Nabi khusus bagi ternak yang tidak digembalakan dan tidak bermaksud untuk membebaskan ternak yang digembalakan dari kewajiban zakat;

5. Mafbüm al-mukhālafah tidak menyimpang dari realitas atau 
ketentuan khusus di mana teks diketahui mempertimbangkannya. Misalnya dalam masalah hubungan muslim dan non muslim. AlQuran menyatakan jangan biarkan orang mukmin berkawan dengan orang kafir. Ayat ini tampaknya melarang kita berhubungan dengan orang kafir tapi ini bukanlah tujuan hakiki dari ayat itu karena ia diturunkan di dalam persoalan khusus yaitu mengenai orang-orang mukmin yang secara eksklusif berkawan dengan orang kafir. Mereka dilarang melakukan hal ini bukan lantaran tidak boleh bersahabat dengan orang kafir. Dengan kata lain ayat ini menggambarkan suatu kejadian khusus dan tidak menjadi prinsip umum;

6. Mafbüm al-mukhälafah tidak membawa kesimpulan yang bertentangan dengan ketentuan teks yang lain seperti dalam ayat qisas dinyatakan "qisas ditetapkan bagi kamu dalam kasus-kasus pembunuhan orang merdeka dengan orang merdeka.....”. Teks ini tidak diberlakukan dengan mafbum al-mukhälafah sehingga muncul kesimpulan bahwa seorang laki-laki tidak dihukum karena membunuh seorang wanita. Ketentuan seperti ini bertentangan dengan keterangan eksplisit ayat al-Quran lain yang menjelaskan tentang qisas yang menuntut qisas bagi semua jenis pembunuhan. ${ }^{16}$

Pembatasan pokok yang ditegaskan oleh ulama-ulama Hanafiah dalam soal mafhüm al-mukhālafah adalah bahwa ia tidak boleh diterapkan kepada teks wahyu yaitu al-Qur'an dan sunnah. Jadi sebagai metode interpretasi, mafhüm al-mukhälafah hanya disahkan pemakaiannya dalam kaitan teks yang bukan wahyu. Hanya dalam konteks yang berkaitan dengan dalil-dalil akli dan hukumhukum buatan manusia mafbüm al-mukbälafah dapat menjadi dasar yang valid bagi hukum dan ijtihad. Alasan utama yang dikemukakan oleh ulama Hanafiah adalah bahwa al-Qur'an sendiri tidak mempercayai pengunaan mafhüm al-mukhälafah, karena ada banyak

${ }^{16}$ Kamali, Prinsip-Prinsip, hal. 170-172; Yahya dan Fathurahman, Dasar-Dasar, hal. 310. 


\section{Marwadi}

petunjuk di dalam al-Qur'an dan Sunah yang maknanya akan keliru jika mereka mengunakan interpretasi mafbüm al-mukhälafah.

Contohnya dapat kita baca dalam al-Qur'an mengenai jumlah bulan yang ditetapkan-Nya pada waktu Ia mencipkan jagat raya bahwa ada dua belas bulan dalam setahun. Nas itu kemudian menyatakan empat dari dua belas bulan itu adalah sakral sehingga harus dihindari adanya penyerangan pada bulan-bulan tersebut. Dengan jalan mafbum al-mukhälafah bisa diambil pengertian bahwa selain bulan yang empat maka dibolehkan. Maka ini jelas menyimpang dari tujuan teks karena penyerangan selalu dilarang tanpa melihat waktunya. ${ }^{17}$

\section{Argumen a Fortiori dan Argumen a Contrario dalam Hukum Positif}

Dengan adanya kodifikasi, hukum itu lalu menjadi beku, statis dan sukar berubah. Adapun yang selalu melaksanakan kodifikasi hukum adalah hakim, karena dialah yang berkewajiban menegakkan hukum ditengah-tengah masyarakat.

Walaupun kodifikasi telah diatur selengkap-lengkapnya, namun tetap juga kurang sempurna dan masih terdapat banyak kekurangan hingga menyulitkan dalam pelaksanannya. Hal ini disebabkan karena pada waktu kodifikasi dibuat ada hal-hal yang belum dikenal. Oleh karena hukum bersifat dinamis, maka hakim sebagai penegak hukum hanya memandang kodifikasi sebagai pedoman agar ada kepastian hukum, sedangkan di dalam memberi putusan hakim harus juga mempertimbangkan dan mengingat perasaan keadilan yang hidup dalam masyarakat. Dengan demikian maka terdapat keluwesan hukum (rechtslenigheid) sehingga hukum kodifikasi berjiwa hidup dan dapat mengikuti perkembangan zaman. ${ }^{18}$ Nyatalah untuk memberi keputusan seadil-adilnya seorang hakim harus mengingat pula adat istiadat, yurisprudensi, ilmu pengetahuan dan akhirnya pendapat

${ }^{17}$ Kamali, Prinsip-Prinsip, hal. 175.

${ }^{18}$ Sudikno Mertokusumo dan A. Pitlo, Bab-Bab Tentang Penemuan Hukum, Bandung: Citra Agitya Bakti, 1993, hal. 4. 
hakim sendiri ikut menentukan dan untuk itu perlu penafsiran hukum. ${ }^{19}$

Penafsiran analogis memberi tafsiran pada suatu peraturan hukum dengan memberi ibarat (kiyas) pada kata-kata tersebut sesuai dengan asas hukumnya, sehingga suatu peristiwa yang sebenarnya tidak dapat dimasukkan lalu diangap sesuai dengan bunyi peraturan tersebut, misalnya menyambung aliran listrik dianggap sama dengan "mengambil" aliran listrik sehingga sama-sama tergolong "pencurian". ${ }^{20}$

Contoh lain dari penafsiran analogis adalah perkataan "jual beli” dalam pasal 1576 KUH Perdata Indonesia, di mana ditegaskan bahwa jula beli tidak memutuskan hubungan sewa menyewa sebelumnya. Perkataan jual beli di sini lazimnya diperluas pengertiannya melalui metode analogi sehingga tidak hanya mencakup jual beli saja saperti yang disebutkan dalam pasal tersebut, melainkan juga mencakup perpindahan milik lainnya seperti tukar menukar, penghibahan, pewarisan dan lain-lain. ${ }^{21}$

Dalam ilmu hukum positif juga dijelaskan tentang penafsiran a contrario yaitu suatu cara penafsiran undang-undang yang didasarkan pada perlawanan pengertian antara soal yang dihadapi dan soal yang diatur dalam suatu pasal undang-undang. Dengan berdasarkan perlawanan pengertian (pengingkaran) itu ditarik kesimpulan, bahwa soal yang dihadapi itu tidak diliputi oleh pasal yang termaksud atau dengan kata lain berada di luar pasal tersebut.

Contoh dalam Pasal 34 KUHS menentukan bahwa seorang perempuan tidak diperkenankan menikah lagi sebelum lewat 300 hari setelah perkawinannya terdahulu diputuskan. Timbullah kini pertanyaan bagaimana halnya dengan laki-laki apakah seorang laki-

${ }^{19}$ C.S.T. Kansil, Pengantar Ilmu Hulum Dan Taia Hukum Indonesia, Jakarta: Balai Pustaka, 1986, hal. 66.

${ }^{20}$ Ibid., hal. 68.

${ }^{21}$ R. Subekti, Aneka Perjanjian, Bandung: PT Citra Aditya Bhakti, 1992, hal. 48. Lihat juga R. Subekti dan R. Tjitrosudibyo, KUH Perdata, Jakarta: PT Pradnya Paramita, 1995, hal. 385 . 


\section{Marwadi}

laki juga harus menunggu lampaunya waktu 300 hari?. Jawaban atas pertanyaan ini tidak, karena pasal 34 KUHS tidak menyebutkan apaapa tentang orang laki-laki dan khusus ditujukan kepada seorang perempuan.

\section{E. Penutup}

Dalam hukum Islam maupun hukum positif sama-sama ada pemahaman yang diperluas dari hukum yang tersurat, baik melalui argumen a fortiori maupun melalui argumen a contrario.

Dalam hukum Islam, terdapat perbedaan para ulama ketika menyikapi apakah argumen a fortiori termasuk dalam analogi atau pemahaman linguistik saja. Satu kelompok menganggapnya sebagai analogi dan kelompok lainnya menganggap sebagai analisis linguistik murni. Imam al-Ghazali mengambil jalan tengah di antara keduanya dan mengatakan bahwa argumen a fortiori tidak termasuk analogi dan juga bukan analisis linguistik saja. Menurutnya argumen a fortiori adalah memahami makna yang tidak tersurat melalui ungkapan tersurat dengan petunjuk konteks dan maksud pernyataan. Jadi gabungan antara analogi dengan pemahaman secara linguistik secara bersamaan.

Kajian argumen a fortiori maupun argumen a contrario dalam hukum Islam lebih luas, karena dalam hukum Islam dibedakan antara panafsiran analogi dengan argumen a fortiori, sedangkan dalam hukum positif tidak tampak perbedaan antara analogi dengan argumen lainnya. 


\section{DAFTAR PUSTAKA}

Anwar, Syamsul. "Argumentum A Fortiori dalam Metode Penemuan Hukum Islam” dalam Sosio-Religia, 1, 3 (2002).

As-Syafi'i. Ar-Risalah, terj. Ahmadi Thoha. Jakarta: Pustaka Firdaus, 1983.

Al-Zuhayli, Wahbah. Ușūl al-Fiqh al-Islämì. Beirut: Dar al-Fikr, 1986.

Badrān, Badrān Abū al-'Aynayn. Ușūl al-Fiqh al-Istamìi. Iskandariyah: Mu'asssasah Syabāb al-Jāmi'ah, t.t.

Kamali, Muhammad Hashim, Prinsip-prinsip dan Teori Hukum Islam, terj. Nurhaidi, Yogyakarta: Pustaka Pelajar, 1996.

Kansil, C.S.T. Pengantar Ilmu Hukum Dan Tata Hukum Indonesia. Jakarta: Balai Pustaka, 1986.

Khallāf, 'Abd al-Wahhāb. 'Ilm Ușül al-Fiqh. Ttp.: Dār al-'Ilm, 1978.

Khudari Bik. Ușül al-Figh. Ttp. Dar al-Fikr, 1988.

Mertokusumo, Sudikno dan A. Pitlo. Bab-Bab Tentang Penemuan Hukum. Bandung: Citra Agitya Bakti, 1993.

R. Subekti. Aneka Perjanjian. Bandung: PT Citra Aditya Bhakti, 1992.

R. Subekti dan R. Tjitrosudibyo. KUH Perdata. Jakarta: PT Pradnya Paramita, 1995.

Yahya, Muhtar dan Fathurahman. Dasar-Dasar Pembinaan Hukum Fiqh Islam. Bandung: Alma'arif, 1993. 
Marwadi 